\title{
ANALISIS PERSEPSI PESERTA DIDIK TERHADAP PENGGUNAAN NOVEL GRAFIS MELALUI PEDAGOGI MULTILITERASI
}

\author{
Teddy Fiktorius \\ SMA Bina Mulia Pontianak, Kalimantan Barat \\ fiktoriusteddy@yahoo.com
}

(Diterima: 27 Agustus 2020; Disetujui:17 Desember 2020; Publikasi: 31 Desember 2020)

\begin{abstract}
ABSTRAK
Tujuan utama dari studi kasus ini adalah untuk menganalisis persepsi dari 27 peserta didik SMA Bina Mulia dalam membaca novel grafis menggunakan pedagogi multiliterasi yang mencakup desain pembelajaran yang seimbang dari 'mengalami', 'mengonsep', 'menganalisis' dan 'menerapkan'. Studi kasus ini melibatkan pengumpulan data kualitatif yang berasal dari observasi dan wawancara kelompok fokus. Temuan penelitian ini menunjukkan bahwa peserta didik secara positif menilai penerapan kegiatan membaca novel grafis sebagai strategi implementasi multiliterasi karena kegiatan ini tidak hanya dapat meningkatkan minat baca peserta didik tetapi juga memotivasi mereka untuk belajar dengan rekan-rekannya secara kolaboratif.
\end{abstract}

Kata Kunci: Persepsi, novel grafis, multiliterasi, minat baca

\begin{abstract}
The main objective of this case study was to analyse the perceptions of 27 students of SMA Bina Mulia in reading graphic novels using a multiliteracies pedagogy which included a balanced learning design of "experiencing", "conceptualising", "analysing" and "applying". This case study involved collecting qualitative data derived from observation and focus group interviews. The findings of this study indicated that students positively assess the application of reading graphic novels as a multiliterate implementation strategy because this activity could not only increase their reading interest but also motivate them to learn with their peers collaboratively.
\end{abstract}

Keywords: perception, graphic novel, multiliterate, interest in reading

\section{PENDAHULUAN}

Pesatnya perkembangan global telah membawa dampak yang luar biasa terhadap lanskap pendidikan Indonesia. Fenomena ini terlihat semakin jelas seiring semakin meningkatnya keanekaragaman budaya dan bahasa yang kemudian menghasilkan tantangan dan peluang pendidikan. Dalam lingkup pendidikan Indonesia, pemangku kepentingan sekolah ditantang untuk menemukan strategi literasi dan metode pedagogis yang paling sesuai bagi peserta 
didik dalam keanekaragaman tersebut. Upaya ini bertujuan untuk meningkatkan pencapaian literasi guna memenuhi tuntutan kelas global. Baguley, Pullen \& Short (2010) berpendapat bahwa kelas global adalah lingkungan di mana kemajuan teknologi telah mengambil peran dalam menciptakan cara-cara pengajaran dan pembelajaran yang inovatif. Peran ini menyoroti kolaborasi positif antara praktik literasi multimodal dan penggunaan Teknologi informasi dan komunikasi (TIK) untuk mendorong motivasi belajar yang akhirnya dapat memicu hasil pembelajaran yang positif (Ganapathy, 2014).

Dalam konteks pencapaian literasi, Indonesia menempati peringkat ke-60 di antara 61 negara berdasarkan penelitian yang dilakukan oleh Central Connecticut State University pada tahun 2016 sebagaimana diberitakan oleh Kompas.com pada tanggal 29 Agustus 2016. Secara khusus, dalam lingkup pengajaran dan pembelajaran bahasa Inggris di Indonesia, banyak pelajaran membaca di kelas yang tampaknya telah mengabaikan unsur kesenangan dan keterlibatan peserta didik dalam membaca. Fenomena ini telah menyebabkan banyak peserta didik di Indonesia menjadi tidak tertarik untuk membaca materi bahasa Inggris sebagaimana telah didokumentasikan dalam beberapa penelitian di Indonesia (Iftanti, 2012; Fahmi, 2016; Salikin, Tahir, Kusumaningputri, \& Yuliandari, 2017; Syawal \& Tahir, 2017).

Pada ranah pengajaran dan pembelajaran bahasa Inggris di tempat kerja peneliti, yakni SMA Bina Mulia Pontianak, Kalimantan Barat, peneliti mengidentifikasi beberapa masalah berdasarkan hasil survei sederhana. Lebih terperinci, survei dilaksanakan pada tanggal 28 Januari 2019 di kelas 11 MIA yang terdiri atas 27 peserta didik. Hasil survei menunjukkan 26 peserta didik atau 96\% tidak menyukai kegiatan membaca bahasa Inggris dan hanya 1 peserta didik atau $4 \%$ yang menyukai membaca namun dengan catatan bahwa isi bacaan harus menarik. Selanjutnya, masalah demikian juga diklaim dapat berpengaruh terhadap motivasi belajar peserta didik pada mata pelajaran bahasa Inggris.

Masalah-masalah tersebut berimplikasi terhadap pentingnya implementasi solusi efektif berupa instruksi literasi yang memungkinkan peserta didik untuk memeroleh pengetahuan dan keterampilan literasi dari berbagai perspektif. Hal ini hanya dapat dicapai melalui pendekatan multimodal dalam peningkatan literasi. Pada era Revolusi Industri 4.0, muncul desakan untuk mengubah metode konvensional ke strategi efektif yang mempromosikan minat baca di antara para peserta didik. Oleh karena itu, guru diharapkan untuk lebih menekankan pada penggabungan teknologi dan materi yang sesuai ke dalam pelajaran membaca untuk membuat pelajaran lebih menyenangkan bagi peserta didik. Argumen ini didukung oleh Gleason (2018) yang menjelaskan bahwa pergeseran dari pendekatan literasi tradisional ke literasi modern menyoroti pentingnya multimodal dan 
multiliterasi yang memungkinkan orang untuk belajar di mana saja dan kapan saja melalui berbagai macam media pembelajaran.

Secara praktis, membaca novel grafis melalui pendekatan multiliterasi layak dilaksanakan di kelas karena strategi ini dapat membantu peserta didik untuk menjadi warga dunia multikultural dan digital. Penggunaan novel grafis melalui pendekatan multiliterasi memiliki potensi untuk memotivasi peserta didik karena membantu mereka membangun literasi visual dalam suasana yang menyenangkan. Hal ini dimungkinkan mengingat novel grafis adalah perpaduan sempurna antara rangkaian kata dan gambar sebagai seni. Selanjutnya, novel grafis menawarkan pengalaman multiliterasi yang efektif, efisien dan unik. Secara luas dikutip bahwa novel grafis sekarang umum digunakan dalam berbagai pelajaran membaca di seluruh dunia (Brenna, 2013; Cimermanová, 2014; Maureen, Beverley, \& Cheryl, 2014; Thusha, 2015; Öz \& Efecioğlu, 2015; Basal, Aytan \& Demir, 2016).

Dengan pengantar yang dielaborasikan di atas, penelitian ini mengajukan argumen bahwa ada kebutuhan mendesak untuk membantu peserta didik mengeksplorasi cara belajar inovatif yang dapat memberi mereka pengalaman belajar yang menyenangkan. Khususnya, ada urgensi untuk melihat lebih dekat pada penggunaan model pedagogis multiliterasi yang dikembangkan oleh the New London Group (1996) dalam membaca novel grafis. Penelitian ini bertujuan untuk menyelidiki persepsi peserta didik dalam membaca novel grafis menggunakan pedagogi multiliterasi dalam upaya untuk mendongkrak minat baca peserta didik sebagai tuntutan era Revolusi Industri 4.0.

\section{NOVEL GRAFIS DALAM RANAH PENDIDIKAN}

Saat ini, novel grafis mulai menemukan tempat di ruang kelas mengingat pendidikan saat ini perlu didukung dengan materi yang sesuai. Bahan bacaan yang sering dipakai tidak lagi memadai untuk memenuhi kebutuhan generasi saat ini. Oleh karena itu, penggunaan novel grafis dipandang sebagai solusi. Dengan membaca teks dan gambar, peserta didik mengembangkan tidak hanya keterampilan membaca mereka tetapi juga kemampuan analitis mereka dengan mengevaluasi bagaimana gambar berfungsi sesuai teks. Argumen perihal multimodal didukung oleh Cloonan (2015) dan Thusha (2015) yang menegaskan bahwa kombinasi lebih dari satu sistem semiotik dalam teks menghasilkan teks multimodal. Oleh karena itu, novel grafis tergolong multimodal karena merangkul berbagai mode seperti gambar, warna dan tulisan.

Penggunaan novel grafis dalam konteks pendidikan telah memicu berbagai pendapat. Sebagaimana ditunjukkan oleh Hansen (2012) dan Askin (2013), penggunaan novel grafis 
Teddy Fiktorius

Analisis Persepsi Peserta Didik Terhadap Penggunaan Novel Grafis Melalui Pedagogi Multiliterasi

dalam konteks pendidikan memiliki sisi gelapnya. Pertama, sebagian guru berpendapat bahwa membaca novel grafis hanya dianggap sebagai kegiatan rekreasi di waktu luang. Beberapa orang tua dan guru bahkan mengaitkan novel grafis dengan konten kekerasan, bahasa orang dewasa, dan gambar vulgar. Selain itu, penggunaan novel grafis sebagai alat pengajaran juga diklaim membawa kesulitan praktis di kelas berkaitan dengan kegiatan membaca nyaring. Pada akhirnya, tantangan terbesar adalah terkait integrasi penggunaan novel grafis ke dalam kurikulum.

Bertentangan dengan pandangan negatif yang ada, sejumlah guru bahasa Inggris mengandalkan kekayaan dalam literasi visual novel grafis untuk mengajarkan aspek sastra. Peserta didik secara aktif menyimpulkan apa yang mereka lihat dari gambar dan menghubungkannya dengan teks yang sesuai untuk memahami narasi yang berkembang dari gambar ke gambar. Membaca novel grafis dapat memicu motivasi intrinsik peserta didik. Mereka tidak merasa terpaksa membaca karena mereka menyukai bacaan berwarna-warni. Öz \& Efecioğlu (2015) mengklaim bahwa manfaat ini memainkan peran penting dalam mentransfer peserta didik menjadi pembelajar mandiri. Mereka dilatih untuk menyimpulkan pesan-pesan tersembunyi, menebak makna kosakata melalui gambar dan mendapatkan ide keseluruhan tanpa bertanya kepada guru atau mencari arti kata-kata dalam kamus mereka.

Dalam konteks Indonesia, penggunaan novel grafis di ruang kelas memiliki sejarah singkat; karenanya, hanya sedikit literatur dan penelitian yang bisa ditemukan. Akan tetapi, ada beberapa penelitian internasional yang mendokumentasikan penggunaan novel grafis di ruang kelas. Studi yang dilakukan Cimermanova (2014) dan Basal, Aytan, \& Demir (2016) menunjukkan efisiensi novel grafis dalam pengajaran kosakata. Selanjutnya, Thusha (2015) menekankan penggunaan novel grafis sebagai media multimodal alternatif. Kemudian, Öz \& Efecioğlu (2015) menyerukan untuk memasukkan novel grafis ke dalam silabus karena materi ini lebih menarik bagi indra visual peserta didik dibandingkan dengan teks tradisional. Selain itu, Maureen, Beverley, \& Cheryl (2014) merekomendasikan penggunaan novel grafis sesuai usia untuk penggunaan ruang kelas umum selain sebagai bahan pendukung pendidikan khusus. Selanjutnya, sebuah studi yang dilakukan oleh Brenna (2013) mendukung penggunaan novel grafis sebagai sumber daya untuk membantu mengembangkan strategi literasi kritis.

\section{MULTILITERASI DALAM KERANGKA TEORETIS DAN PRAKTIS}

Terdapat sepuluh (10) akademisi literasi dari Amerika Serikat, Inggris dan Australia (The New London Group) menciptakan istilah 'multiliteracies' pada tahun 1996. Mereka 
Teddy Fiktorius

Analisis Persepsi Peserta Didik Terhadap Penggunaan Novel Grafis Melalui Pedagogi Multiliterasi

mengusulkan rekonseptualisasi literasi untuk menghadapi munculnya ekonomi global yang telah merevolusi dunia kontemporer dalam hal penyebaran dan penggunaan bahasa Inggris global dan kemajuan teknologi yang telah menghasilkan akses yang lebih luas terhadap teksteks multimodal yang tidak hanya menggunakan ragam tulisan, tetapi juga visual, audio dan gestur.

Untuk mengarahkan pengetahuan dan keterampilan abad ke-21 ke dalam konteks pembelajaran, the New London Group (1996) menyarankan empat komponen, yaitu situated practice', 'overt instruction', 'critical framing' dan 'transformed practice'. Istilah-istilah tersebut diuraikan sebagai berikut.

- Dalam situated practice (latihan terkondisi), guru bersama peserta didik mengeksplorasi pengetahuan dan keterampilan peserta didik yang ada melalui materi multimodal yang mencakup teks, audio dan visual.

- $\quad$ Dalam overt instruction (instruksi yang jelas), guru memfasilitasi pembelajaran melalui proses scaffolding menggunakan pengajaran langsung. Guru mencoba menjembatani pengetahuan dan keterampilan peserta didik yang ada untuk mendapatkan informasi dan pengetahuan baru melalui interaksi dengan materi multimodal dan teknologi.

- Dalam critical framing (kerangka berpikir kritis), peserta didik terlibat dalam kegiatan pembelajaran yang mendorong keterampilan berpikir tingkat tinggi yang mencakup kemampuan berpikir dan analisis kritis.

- Dalam transformed practice (praktik transformatif), peserta didik difasilitasi untuk mengubah pengetahuan dan keterampilan yang ada ke konteks sosial baru yang bertujuan untuk menciptakan pengetahuan dan keterampilan baru.

Dalam menerapkan ide-ide tersebut ke praktik kurikulum selama dekade terakhir, Cope \& Kalantzis (2015) membingkai istilah-istilah tersebut ke dalam proses pengetahuan yang lebih mudah dikenali, yaitu 'experiencing' (mengalami), 'conceptualising' (mengonsep), 'analysing' (menganalisis) dan 'applying' (menerapkan). Proses pengetahuan ini sangat penting untuk merancang serangkaian pembelajaran yang disorot dalam pendekatan multiliterasi. Topik, isi pembahasan dan tujuan pembelajaran yang sesuai juga akan berkontribusi pada keefektifan proses pembelajaran. Konsep pendekatan multiliterasi terhadap pedagogi dalam proses pengetahuan tersebut ditunjukkan pada berikut ini. 


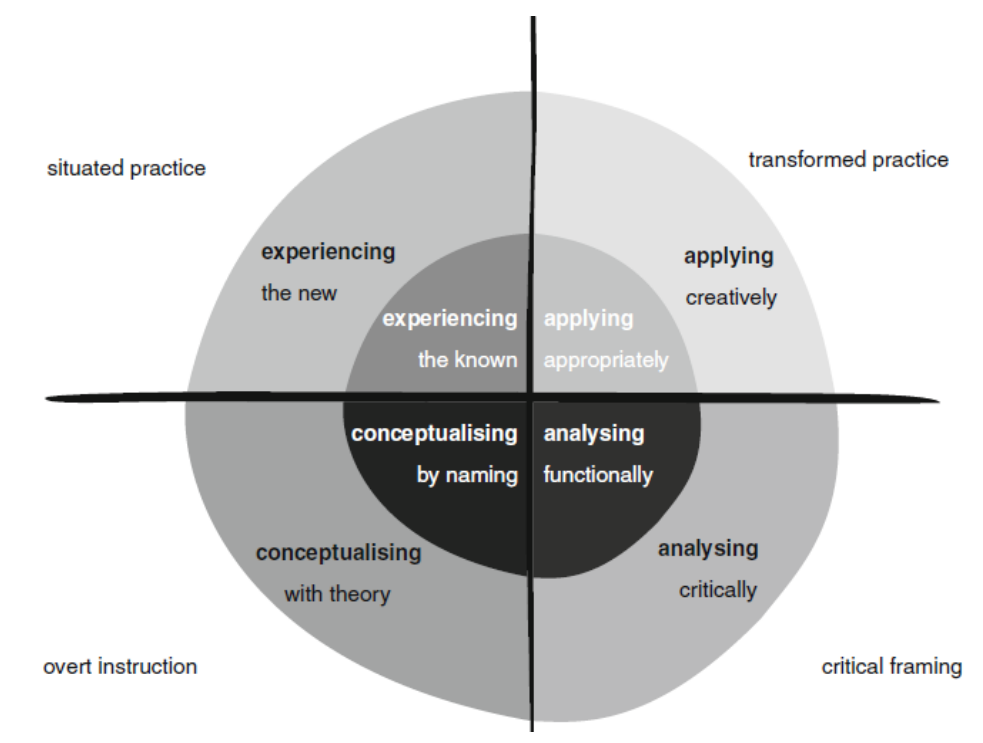

Gambar 1. Pemetaan Pedagogi Multiliterasi terhadap Proses Pengetahuan (Cope dan Kalantzis, 2015:5)

Sebuah penelitian terkini di bidang multiliterasi di Indonesia memberikan beberapa wawasan tentang bagaimana pendekatan pedagogis ini digunakan di kelas. Khairi, Retnaningdyah, dan Aswandi (2018) melakukan studi tentang penggunaan pendekatan multiliterasi untuk mempromosikan keterlibatan peserta didik di kelas pembelajaran bahasa Inggris. Temuan ini menunjukkan implikasi positif dari pendekatan multiliterasi pada kualitas pengajaran dan pembelajaran di antara guru dan peserta didik di sekolah. Tanggapan positif oleh guru dan peserta didik dalam penelitian tersebut menunjukkan bahwa pendekatan multiliterasi sangat relevan untuk diterapkan pada kelas pembelajaran bahasa Inggris di Indonesia.

\section{METODE}

Penelitian ini berbasis pada pendekatan kualitatif guna memahami fenomena minat baca peserta didik secara mendalam. Penelitian ini bersifat deskriptif dengan menggunakan landasan teori sebagai panduan untuk memfokuskan penelitian serta mengutamakan proses dan makna dalam fenomena tersebut. Desain penelitian ini adalah studi kasus yang berfokus pada penyelidikan dan pemahaman terhadap minat membaca peserta didik dalam relevansinya dengan kegiatan membaca novel grafis menggunakan pedagogi multiliterasi.

Penelitian ini dilaksanakan di Sekolah Menengah Atas (SMA) Bina Mulia yang berlokasi di Pontianak, Kalimantan Barat. Sekolah swasta yang didirikan pada tahun 2005 ini memeroleh peringkat akreditasi A dengan nilai 97. Populasi penelitian ini adalah 167 peserta didik SMA Bina Mulia pada tahun pelajaran 2018/2019. Peneliti menerapkan purposive sampling dengan pertimbangan bahwa peneliti sendiri mengetahui persis segala kriteria yang 
tepat bagi sampel untuk menghasilkan informasi maupun data penelitian yang relevan. Kriteria yang harus dipenuhi oleh peserta didik SMA Bina Mulia untuk dapat dipilih sebagai sampel partisipan adalah bahwa peserta didik merupakan anak didik peneliti dalam kegiatan belajar mengajar (KBM) sehari-hari yang memiliki kemampuan bahasa Inggris dan minat baca yang bervariasi. Dengan memerhatikan pemenuhan kriteria tersebut, maka yang menjadi sampel partisipan adalah peserta didik kelas 11 MIA SMA Bina Mulia pada tahun pelajaran 2018/2019. Selanjutnya, novel grafis 'Preparedness 101: Zombie Pandemic' yang berjumlah 36 halaman dipilih dengan pertimbangan kesesuaian isi bacaan dengan usia peserta didik.

Peneliti menerapkan teknik triangulasi untuk memastikan keabsahan data dengan memeriksa kebenaran data dari berbagai sudut pandang dan mengurangi bias yang terjadi saat pengumpulan dan analisis data. Peneliti mengandalkan beragam data yang dijadikan pembanding, yakni hasil studi pustaka, observasi dan wawancara. Lebih jauh, peneliti melakukan penjaminan mutu validitas untuk memastikan keabsahan data melalui validitas isi (content validity) dengan memastikan instrumen pengumpulan data (observasi dan wawancara) mencakup keseluruhan lingkup isu yang diukur. Pada akhirnya, peneliti juga menjamin mutu reliabilitas terkait konsistensi data dengan menghindari ambiguitas diksi pertanyaan dalam instrumen dan menjaga mood responden ketika pengumpulan data berlangsung. Peneliti melaksanakan teknik pengumpulan data sebagai berikut.

\section{Studi Pustaka}

Peneliti mengumpulkan segala informasi yang terkait dengan kegiatan membaca novel grafis dan pedagogi multiliterasi. Informasi tersebut diperoleh dari buku ilmiah, laporan penelitian, dokumen peraturan dan sumber-sumber lainnya baik cetak maupun elektronik. Tujuan dari studi pustaka ini adalah untuk mendapatkan landasan teori yang mutakhir untuk menjawab masalah penelitian.

\section{Observasi}

Observasi dilaksanakan peneliti melalui pendekatan kualitatif dalam bentuk format deskriptif untuk mengetahui respons peserta didik saat penerapan kegiatan membaca novel grafis melalui pedagogi multiliterasi. Peneliti terlibat sebagai partisipan sekaligus pengamat yang memungkinkan peneliti untuk terlibat langsung dalam subjek yang diamati, berinteraksi sekaligus mengamati dan pada akhirnya menarik kesimpulan.

\section{Wawancara}

Peneliti melaksanakan wawancara kelompok fokus (focus group interview) untuk melengkapi data yang terkumpul dari observasi. Metode wawancara dipilih karena peneliti dapat lebih dekat dengan narasumber sehingga informasi yang diperoleh lebih mendalam. Peserta didik 
diminta untuk memberikan pendapat mereka mengenai implementasi kegiatan membaca novel grafis melalui pedagogi multiliterasi. Kode diberikan kepada setiap peserta untuk memastikan anonimitas di mana 27 peserta dibagi menjadi 5 kelompok fokus yang terdiri dari tiga kelompok dengan lima peserta dan dua kelompok dengan enam peserta. Kode 'P1KF1' berarti 'Peserta 1-Kelompok Fokus 1' dan seterusnya.

Sebelum wawancara kelompok fokus, rincian dari penelitian ini dipaparkan kepada peserta untuk memastikan kerjasama yang optimal. Peserta diberitahu bahwa respons mereka dijaga kerahasiaannya dan hanya digunakan untuk tujuan akademis. Peserta diyakinkan bahwa anonimitasnya terjaga sepanjang penelitian. Akhirnya, peneliti menginformasikan bahwa jawaban mereka tidak dievaluasi berdasarkan jawaban yang benar dan salah.

Pada tahap prosedur pelaksanaan, sebelum proses belajar mengajar, guru secara menyeluruh memeroleh pengetahuan tentang elemen pembelajaran di bawah kerangka multiliterasi yang diintegrasikan ke dalam kegiatan membaca novel grafis 'Preparedness 101: Zombie Pandemic'. Para peserta didik diarahkan melalui empat proses pengetahuan dari pedagogi multiliterasi. Proses-proses ini, seperti yang dijelaskan oleh Cope \& Kalantzis (2015), diuraikan sebagai berikut.

Dalam 'experiencing' (mengalami), guru dan peserta didik mengeksplorasi pengetahuan dan keterampilan peserta didik yang ada melalui penggunaan novel grafis 'Superman: The Doomsday Wars'. Kemudian, dalam 'conceptualising' (mengonsep), guru menjembatani pengetahuan dan keterampilan peserta didik yang ada ke informasi dan pengetahuan baru melalui interaksi dengan novel grafis. Selanjutnya, dalam 'analysing' (menganalisis), peserta didik terlibat dalam kegiatan pembelajaran yang mendorong pemikiran kritis dan analitis terkait elemen novel grafis, yaitu tempat dan waktu kejadian, karakter dan karakteristik, alur cerita, tema dan nilai-nilai moral yang terkandung di dalam cerita novel grafis. Akhirnya, dalam 'applying' (menerapkan), para peserta didik difasilitasi untuk mengubah pengetahuan dan keterampilan mereka yang ada ke dalam bentuk presentasi PowerPoint.

Dalam proses analisis data, peneliti menerapkan pendekatan dalam perspektif filosofis consumer-oriented (berorientasi pada pengguna). Lebih terperinci, pendekatan yang berorientasi pada pengguna menonjolkan pentingnya penilaian terhadap keefektifan, hasil, pengaruh dan relevansi suatu perlakuan yang bersumber dari sudut pandang pengguna atau orang yang mendapatkan perlakuan tersebut (Kumar, 2011). 
Teddy Fiktorius

Analisis Persepsi Peserta Didik Terhadap Penggunaan Novel Grafis Melalui Pedagogi Multiliterasi

\section{HASIL PENELITIAN}

Hasil penelitian yang diperoleh dari data hasil observasi dan wawancara mencerminkan persepsi peserta didik dalam membaca novel grafis 'Preparedness 101: Zombie Pandemic' dengan menggunakan pendekatan multiliterasi yang melibatkan penggunaan teknologi. Secara umum, disimpulkan bahwa tanggapan mereka menekankan dua aspek berdasarkan dua pertanyaan penelitian ini. (1) Bagaimana persepsi peserta didik terhadap aspek kesenangan dalam kegiatan membaca novel grafis menggunakan pedagogi multiliterasi dalam upaya untuk mendongkrak minat baca?

Aspek kesenangan dalam kegiatan membaca novel grafis menjadi alasan utama mereka begitu terlibat dalam kegiatan tersebut. Semua peserta didik merasa termotivasi dalam kegiatan membaca novel grafis menggunakan pendekatan multiliterasi karena mereka mendapatkan kesenangan melalui visual yang menarik dan penggunaan teknologi. Berikut ini adalah beberapa kutipan dari wawancara kelompok fokus.

"Mmm.... membaca novel grafis sepertinya pelajaran membaca paling seru. Saya biasanya merasa bosan untuk membaca karena saya merasa pusing dengan teks-teks yang begitu banyak. Hehe.... Tapi, ini tidak terjadi pada saya kali ini. Saya suka gambar-gambar berwarna dalam novel grafis." (P2-KF1)

"Luar biasa! Haha. Gambar-gambar dalam novel grafis itu banyak membantu saya. Saya bisa menebak maknanya. Saya bisa meningkatkan kosa kata saya dengan mudah. Ini akan menjadi hobi baru saya. Hahah....” (P5-KF2)

"Saya belajar banyak dari novel grafis ini. Alur ceritanya membuat saya penasaran. Ada nilai moral yang bisa saya ambil dari ceritanya. Moga cerita ini dibuat menjadi sebuah film. Saya ingin menonton versi filmnya." (P1-KF3)

"Menyiapkan slide presentasi melalui PowerPoint itu paling menyenangkan. Kami memasukkan latar belakang berwarna-warni, gambar lucu, musik dan bahkan gambar selfie kami. Tim kami sangat bersemangat untuk membuat slide yang paling menarik mata!” (P3-KF4)

"Presentasi PowerPoint paling seru. Saya terbantu untuk memahami ceritanya dengan lebih baik. Dari presentasi teman, saya tahu kalau jawaban kami untuk pertanyaan apa pesan moral cerita itu kurang tepat. Hehe..." (P4-KF5)

"Kerja tim kami untuk presentasi layak diacungi dua jempol! Kami membagi pekerjaan kami secara adil dan saksama. Kami ingin menjadi yang terbaik. Saya pikir skor presentasi kami adalah yang tertinggi." (P2-KF2)

(2). Bagaimana persepsi peserta didik terhadap tantangan yang dihadapi ketika terlibat dalam kegiatan membaca novel grafis menggunakan pedagogi multiliterasi dalam upaya untuk mendongkrak minat baca? 
Teddy Fiktorius

Analisis Persepsi Peserta Didik Terhadap Penggunaan Novel Grafis Melalui Pedagogi Multiliterasi

Tanggapan peserta didik juga menunjukkan apa yang dianggap mereka sebagai tantangan utama ketika terlibat dalam kegiatan membaca novel grafis menggunakan pendekatan multiliterasi. Mereka menunjukkan faktor waktu sebagai tantangan utama dalam pelajaran membaca tersebut. Selain itu, kecanggungan mereka yang berhubungan dengan penggunaan teknologi juga tampak jelas. Namun demikian, semua tantangan ini tidak menyulitkan mereka selama kegiatan tersebut. Sebaliknya, tantangan-tantangan ini menjadi pemicu untuk bekerja lebih keras dan lebih cepat. Dalam aspek kolaborasi selama kegiatan, mereka memberikan beberapa komentar positif. Mereka menganggap bahwa tantangan tersebut mendorong kerjasama di antara mereka dalam menyelesaikan tugas. Mereka menyoroti beberapa pandangan menarik tentang masalah ini dalam kutipan dari wawancara kelompok fokus berikut ini.

"Ini adalah pertama kali saya membaca novel grafis. Saya bahkan tidak tahu novel grafis sebelumnya. Ketika saya membacanya, saya sangat menikmati gambar-gambar yang berwarna-warni. Lalu saya lupa tentang waktu. Waktu sudah habis sebelum saya selesai membaca. Oh tidak...." (P5-KF3)

"Momen terbaik dari pelajaran ini adalah ketika kami banyak berdiskusi. Kami berbagi pendapat kami. Sebenarnya, kami memiliki jawaban yang berbeda untuk nilai moral dari cerita. Kami tidak menyadari bahwa kami menghabiskan terlalu banyak waktu untuk argumen ini. Akhirnya, kami terburu-buru menyiapkan slide. Waktu sangat terbatas." (P2-KF1)

"Saya terus melihat jam tangan saya. Waktu berjalan begitu cepat. Saya ingin tim saya menyelesaikan tugas tepat waktu. Saya menjadi lebih gugup ketika melihat slide dari tim lain. Slide mereka memiliki latar belakang warna-warni, animasi dan musik yang bagus. Oh tidak, kami harus lebih baik.” (P3-KF2)

"Saya gugup sekali di depan laptop. Saya tidak mahir merancang slide. Tapi untungnya, rekan tim saya banyak membantu. Mereka sangat jago. Mereka mengajari saya untuk membuat slide yang indah. Untung ada mereka. Mmmm, saya berpikir kerja tim kami yang terbaik." (P1-KF4)

Keseluruhan respons peserta didik dalam observasi dan wawancara menunjukkan bahwa mereka menikmati pelajaran membaca yang menggunakan novel grafis dan pendekatan multiliterasi. Kondisi ini berbanding lurus dengan minat bacanya. Kegembiraan mereka dihasilkan dari gambar visual yang menarik dan penggunaan teknologi melalui PowerPoint. Tantangan yang mereka hadapi selama kegiatan tidak mengurangi kegembiraan mereka. Sebaliknya, mereka menjadi lebih bertekad untuk secara kolaboratif melakukan yang terbaik. 
Teddy Fiktorius

Analisis Persepsi Peserta Didik Terhadap Penggunaan Novel Grafis Melalui Pedagogi Multiliterasi

\section{PEMBAHASAN}

Penggunaan observasi dan wawancara kelompok fokus dalam penelitian ini memberikan gambaran yang komprehensif tentang kegiatan membaca novel grafis sebagai media multimodal untuk pendidikan dan pendekatan multiliterasi sebagai kerangka pedagogis untuk kegiatan pengajaran dan pembelajaran. Melalui data ini, peneliti mampu menambah kedalaman pemahaman perihal fenomena yang menarik ini.

Dalam penelitian ini, peserta didik menunjukkan penerimaan positif terhadap kegiatan membaca novel grafis melalui pendekatan multiliterasi. Aspek multimodal merupakan faktor penting untuk meningkatkan kesenangan yang diterima peserta didik dalam belajar. Temuan ini didukung oleh hasil penelitian Cloonan (2015) dan Thusha (2015) yang menyoroti pentingnya penggunaan materi multimodal dalam praktik pedagogi multiliterasi di ruang kelas. Oleh karena itu, novel grafis dengan semua kualitas multimodalnya dipandang sebagai media yang efektif di kelas pembelajaran bahasa Inggris.

Mengacu pada pernyataan tersebut, novel grafis diyakini memiliki karakteristik dan kualitas positif dalam mendukung pelajaran membaca. Selanjutnya, para peserta didik menunjukkan keyakinan yang kuat bahwa novel grafis dan pendekatan multiliterasi adalah alat pedagogis yang berguna dalam mempromosikan proses pembelajaran yang aktif dan kolaboratif melalui materi multimodal dan penggunaan teknologi. Hal ini sejalan dengan hasil penelitian yang dilakukan oleh MacKay (2014) dan Howell (2015) yang mengkonfirmasi keberadaan alat digital yang cocok untuk memproduksi literasi multimodal digital. Kemudian, hasil temuan Cimermanova (2014) merekomendasikan penggunaan novel grafis karena novel grafis membawa materi multimodal otentik yang telah diadopsi berdasarkan dengan minat dan motivasi peserta didik ke kelas pembelajaran bahasa Inggris.

Meskipun terdapat banyak pandangan positif dari para responden terhadap kegiatan membaca novel grafis dengan menggunakan pendekatan multiliterasi, ada beberapa di antara mereka yang menunjukkan beberapa tantangan yang dihadapi oleh mereka, yakni faktor alokasi waktu dan kecanggungan ketika berhadapan dengan teknologi (PowerPoint). Walaupun demikian, mereka merespons tantangan-tantangan tesrsebut dengan cara yang positif karena tantangan tersebut justru memotivasi mereka untuk melakukan yang terbaik dalam menyelesaikan tugas. Mereka mengerti bahwa mereka sangat membutuhkan semangat kerja secara kolaboratif.

Dalam ruang lingkup kolaborasi selama berlangsungnya kegiatan belajar mengajar, peserta didik memberikan komentar yang sangat positif. Mereka meyakini bahwa tantangan itu memicu motivasi internal mereka untuk bekerja sebagai tim yang solid. Hal ini senada 
Teddy Fiktorius

Analisis Persepsi Peserta Didik Terhadap Penggunaan Novel Grafis Melalui Pedagogi Multiliterasi

dengan temuan Öz \& Efecioğlu (2015) yang menekankan motivasi intrinsik peserta didik. Lebih rinci, peserta didik tidak merasa terpaksa untuk membaca sesuatu, mempelajarinya, memecahkan masalah dan melaksanakan keterampilan yang dibutuhkan baik sebagai individu maupun kelompok. Ketika mereka mulai belajar karena motivasi intrinsik mereka, mereka pasti akan memeroleh kesuksesan akademis.

Sebagai kesimpulan, respons sangat positif ditunjukkan oleh para peserta didik terhadap kegiatan membaca novel grafis melalui pedagogi multiliterasi. Respons tersebut menunjukkan bahwa minat baca mereka meningkat seiring dengan kesenangan dan pengalaman kolaboratif yang mereka peroleh dalam kegiatan membaca novel grafis sebagai media multimodal dan pendekatan multiliterasi sebagai kerangka pedagogis digital dalam kegiatan pengajaran dan pembelajaran. Adapun faktor-faktor yang menjadi tantangan mereka selama keterlibatan mereka dalam kegiatan tersebut, yakni alokasi waktu dan kecanggungan teknologi, ditanggapi mereka secara positif dalam wujud semangat kerja kolaboratif.

\section{KESIMPULAN}

Penelitian ini mengeksplorasi persepsi peserta didik dalam membaca novel grafis melalui pedagogi multiliterasi yang dikembangkan oleh the New London Group (1996). Penelitian ini bertujuan untuk memberikan pemahaman tentang bagaimana peserta didik belajar dengan novel grafis melalui pedagogi multiliterasi dan apakah pembelajaran itu diterima baik oleh mereka.

Komponen pembelajaran dirancang dan dilaksanakan sesuai dengan proses pengetahuan yang disarankan oleh Cope \& Kalantzis (2015). Tanggapan dari para peserta didik menunjukkan penerimaan yang hangat terhadap kegiatan membaca novel grafis menggunakan pendekatan multiliterasi. Penggabungan novel grafis dan pendekatan multiliterasi memiliki potensi untuk menciptakan suasana positif di kelas dalam aspek kesenangan dalam membaca dan kolaborasi dalam pembelajaran yang pada akhirnya memberikan efek yang positif terhadap minat baca peserta didik. Tantangan yang dihadapi selama kegiatan tidak memberikan mereka kesulitan tetapi sebaliknya memberikan motivasi bagi mereka untuk bekerja secara kolaboratif.

Penelitian ini memberikan wawasan berharga ke dalam praktik pengajaran dan pembelajaran bahasa Inggris tradisional. Secara khusus, argumen ini menunjukkan perlunya praktik yang relevan di dunia digital era Revolusi Industri 4.0. Temuan penelitian ini juga memberikan wawasan yang berguna tentang urgensi novel grafis dan pedagogi multiliterasi 
dimasukkan ke dalam konteks pengajaran dan pembelajaran sebagaimana didokumentasikan oleh banyak penelitian sebelumnya.

Penelitian ini memiliki dua keterbatasan yang perlu ditangani dalam penelitian masa depan. Pertama, peneliti selaku guru yang melakukan kegiatan belajar mengajar yang bisa saja telah memengaruhi pelaksanaan kegiatan dan interpretasi hasil. Kemudian, penelitian studi kasus berskala kecil ini hanya mencakup sampel kecil. Data yang dikumpulkan dalam penelitian ini terbatas pada persepsi dan praktik dari peserta didik yang dipilih. Oleh karena itu, dimasukkannya berbagai perspektif dari orang tua dan pemangku kepentingan sekolah juga akan berkontribusi pada pemahaman yang lebih lengkap tentang potensi pembelajaran menggunakan novel grafis melalui pendekatan multiliterasi. Meskipun hasilnya tidak dapat digeneralisasikan, temuan dari studi kasus ini dapat berfungsi sebagai dasar untuk penyelidikan lebih lanjut dalam memahami penggunaan novel grafis dan pendekatan multiliterasi di kelas membaca bahasa Inggris sebagai upaya mendongkrak budaya literasi yang fungsional untuk memenuhi kebutuhan peserta didik sesuai tuntutan era Revolusi Industri 4.0.

\section{SARAN}

Berdasarkan kesimpulan dalam penelitian ini, peneliti merekomendasikan beberapa hal sebagai berikut. Pertama, kegiatan membaca novel grafis dalam kerangka pedagogi multiliterasi perlu mendapat tempat di kurikulum dan bahkan Gerakan Literasi Nasional sehingga pelaksanaan kegiatan membaca ini mendapat acuan yang terarah. Kedua, kegiatan membaca novel grafis dalam kerangka pedagogi multiliterasi dapat diterapkan pada satuan pendidikan lain, baik jenjang SD, SMP, SMK dan yang sederajat mengingat landasan teori penerapan kegiatan ini adalah teori linguistik dan literasi yang bersifat universal. Terakhir, kegiatan membaca novel grafis dalam kerangka pedagogi multiliterasi dapat diimplementasikan di mata pelajaran bahasa lainnya, yakni bahasa Indonesia dan bahasabahasa lainnya yang dipelajari di satuan pendidikan mengingat novel grafis tersedia dalam berbagai bahasa.

\section{DAFTAR PUSTAKA}

Askin, H. Y. (2013). Using graphic novels in the classroom. Journal of Language and Literature, 8, 118-131.

Baguley, M., Pullen, D. L., \& Short, M. (2010). Multiliteracies and the new world order". Dalam Darren L. Pullen dan David R. Cole (Eds.), Multiliteracies and technology 
enhanced education: Social practice and the global classroom (hlm. 1-17). Hershey: Information Science Reference (an imprint of IGI Global).

Basal, A., Aytan, T., \& Demir, I. (2016). Teaching vocabulary with graphic novels. English language teaching, 9(9), 95-109.

Brenna, B. (2013). How graphic novels support reading comprehension strategy development in children. Literacy, 47(2), 88-94.

Cimermanova, I. (2014). Graphic novels in foreign language teaching. Journal of Language and Cultural Education, 2(2), 85-94.

Cloonan, A. (2015). Integrating by design: Multimodality, 21st century skills and subject area knowledge". Dalam Bill Cope dan Mary Kalantzis (Eds.), The things you do to know: An introduction to the pedagogy of multiliteracies (hlm. 97-114). New York: Routledge/Falmer Taylor \& Francis E-Library. Palgrave Macmillan.

Cope, B. \& Kalantzis, M. (2015). A pedagogy of multiliteracies: Learning by design. Dalam Bill Cope dan Mary Kalantzis (Eds.), The things you do to know: An introduction to the pedagogy of multiliteracies (hlm. 1-36). New York: Routledge/Falmer Taylor \& Francis E-Library. Palgrave Macmillan.

Fahmi, A. (2016). Investigating reading motivation in Indonesian and English among EFL students. ICTTE, 1(1), 946-955.

Ganapathy, M. (2014). Using multiliteracies to engage learners to produce learning. International journal of e-education, e-business, e-management and e-learning, 4(6), 410-422.

Gleason, N.W. (2018). Introduction. Dalam Nancy W. Gleason (Ed.), Higher education in the era of the fourth industrial revolution (hlm. 1-12). Singapore: Palgrave Macmillan.

Hansen, K. S. (2012). In defense of graphic novels. English Journal, 102(2), 57-63.

Howell, E. (2015). Creating arguments using a multiliteracies approach: A formative experiment. Disertasi tidak diterbitkan. Clemson University.

Iftanti, E. (2012). A survey of the English reading habits of EFL students in Indonesia. TEFLIN Journal, 23(2), 149-164.

Khairi, A., Retnaningdyah, P., \& Aswandi. (2018). Revealing multiliteracies in English as a foreign language classroom. Advances in social science, education and humanities research (ASSEHR), 108, 140-145.

Kumar, R. (2011). Research methodology: A step-by-step guide for beginners. London: SAGE Publications Ltd. 
Kompas.com.(2016).

https://edukasi.kompas.com/read/2016/08/29/07175131/minat.baca.indonesia.ada.di.uru tan.ke-60.dunia, diakses pada tanggal 18 Februari 2019 pukul 22.45 WIB.

MacKay, T. (2014). Multiliteracies theory into practice: An inquiry into junior-level literacy classrooms. Disertasi tidak diterbitkan. University of Toronto.

Maureen, A. S., Beverley, A. B., \& Cheryl, K. K. (2014). Comprehension strategies in practice through a graphic novel study. Journal of Reading Education, 39(2), 17-22.

New London Group. (1996). A Pedagogy of multiliteracies: Designing social futures. Harvard Educational Review, 66(1), 60-92.

Öz, H., \& Efecioğlu, E. (2015). Graphic novels: An alternative approach to teach English as a foreign language. Journal of Language and Linguistic Studies, 11(1), 75-90.

Salikin, H., Tahir, S. Z., Kusumaningputri, R., \& Yuliandari, D. P. (2017). The Indonesian EFL learners' motivation in reading. English Language Teaching, 10(5), 81-90.

Syawal, P. \& Tahir, S. Z. (2017). Investigating Indonesian EFL learners' learning and acquiring English vocabulary. International Journal of English Linguistics, 7(4), 128137.

Thusha, R.R. (2015). Multimodality in Malaysian schools: The case for the graphic novel. The Malaysian Online Journal of Educational Science, 3(2), 11-20. 